\title{
The Influence of the Organizational Justice and Trust to the Leaders on Employee Engagement with Job Satisfaction as Intervening Variable
}

\author{
Anik Herminingsih \\ Management Program, Mercu Buana University Jakarta, Indonesia \\ Meruya Ilir Street, Kembangan, West Jakarta
}

\begin{abstract}
This study aimed to analyze the influence of organizational justice and trust to the leaders on employee engagement, with job satisfaction as an intervening variable. The research was conducted by taking samples of employees from Jabodetabek companies. Primary data were obtained by questionnaire filled by the respondents, then analyzed with simultaneous equations models and processed by AMOS program. The results showed that organizational justice has a significant effect on trust to the leaders. Organizational justice and trust to the leaders have a significant effect on employee job satisfaction. Employees' satisfaction influences significantly employee engagement, while organizational justice and trust to the leaders do not significantly influence employee engagement. It can be concluded that organizational justice and trust to the leaders do not directly influence employee engagement, but through job satisfaction as an intervening variable.
\end{abstract}

KeyWords: employee performance, simultaneous equation model, significant effect

\section{PRELIMINARY BACKGROUND}

One of the employees' attitudes that is very much concerned is engagement which is defined as a cognitive condition, emotion, and behavior of an employee which is directed to achieve the desired results of the organization. Research results show that organizations with employee engagement have positive and significant impacts, as the results of research by Medlin and Green Jr (2008), Robertson et al. (2012), Bagyo (2013), as well as research by Warongan et al (2014). In line with Saks (2006), research by Rashed et al. (2013) shows that employee engagement has a significant correlation with the OCB. Robertson and Cooper (2010) research shows that there is a strong correlation between employee engagement and psychological health conditions of employees.

On the one hand, it is believed that employee engagement is important, but only few studies on the level of employee engagement globally; in 2015 it was showed that only 62 percent of employees who have engagement (Hewitt, 2015). This is supported by the results of research by Fahrani et al. (2015) which states that PT. Semen Gresik, only 49 percent is engaged employees, while the 51 percent is not engaged. Based on these studies, how to build employee engagement still gets much attention and attracts researchers to study the factors that influence it, so they can provide suggestions for the development of employee engagement in the field of human resource management.

Researchers have discovered that high levels of employee engagement are found in employees who have immediate managers with relationship-oriented behavior (Kahn, 1990; May et al., 
2004; Saks, 2006). The findings make sense because of the immediate managers (supervisors) usually interact with their employees on a daily basis, which means that they mostly influence employees in the workplace. The immediate manager is an executive function of integration which is one of the operational functions of human resource management (Hasibuan, 2010). The manager can also be a key factor in creating the disengaged employees, primarily through inconsistent management style which leads to the perception of injustice to the employees (Maslach et al., 2001). The results also state that the trust of employees to their supervisors determine the level of their engagement. (MacLeod and Clarke, 2009; Menguc et al, 2012).

The relationship between job satisfaction and employee engagement has been found by some researchers; and there are classified into two groups. The first group states that job satisfaction is the result of the employees' engagement, among others by Lee (2012), while the second group states that job satisfaction is the factor that encourages employees' engagement, as Robinson et al. (2004: 23), and supported by the research of Abraham (2012).

Based on these descriptions, this study will examine and analyze the employees' perception on their immediate supervisors, and focus on trust and justice as the determining factors of employee engagement, and job satisfaction variable has intervening role of both factors to employee engagement.

\section{RESEARCH PURPOSES}

The purpose of this study is to determine the level of justice perceived by employees, trust to leaders, job satisfaction and employee engagement levels among employees. The study also aims to:

1. To analyze the influence of organizational justice on trust to the leaders.

2. To analyze the influence of organizational justice on employee job satisfaction.

3. To analyze the influence of the trust to the leaders on employee job satisfaction.

4. To analyze the effect of job satisfaction on employee engagement of the employees.

5. To analyze the influence of perceptions of organizational justice on employee engagement.

6. To analyze the effect of trust to the leaders on employee engagement.

\section{REVIEW OF THEORIES, FRAMEWORK AND HYPOTHESES \\ Employee Engagement}

Engagement is defined as a positive attitude, full of meaning and motivation, which is characterized by vigor, dedication and absorption (Schaufeli, 2002 in Breso, Schaufeli, \& Salanova, 2010). Vigor is characterized by high levels of energy, resilience, willingness to try, and not giving up facing challenges. Dedication is marked by feeling valued, enthusiastic, inspiring, rewarding and challenging. Absorption is marked by full concentration on the task or assignment, (Schaufeli \& Bakker, 2003). IES defines employee engagement as a positive attitude held by the employees of the organization and its values. An employee having engagement is aware of the context of business, and works with colleagues to improve their work performance for the organization. Organizations should also work to develop and nurture engagement, which requires a two-way relationship between employers and employees, namely, (Robinson et al., 2004). From the various definitions stated by some of the above figures, it can be deduced that employee engagement is a positive attitude that employees have with full of meaning, energy and high motivation, resilience and willingness to try, and not giving up facing the challenges with full concentration to accomplish a task tailored to the values and goals of the organization. 
Dimensions or aspects of employee engagement consist of three (Schaufeli et al, 2003), namely: 1) Vigor is an aspect that is characterized by high levels of strength and resilience of mental work, the desire to strive at the work, persistent in facing difficulties (Schaufeli \& Bakker, 2003). 2) Dedication aspect is characterized by a feeling of meaningful, enthusiasm, inspiration, pride and challenge in the job (Schaufeli and Bakker, 2003). 3) Absorption aspect is characterized by the concentration and deep interest, serious in work, feeling that time passes so quickly and employees find it difficult to break away from work and forget everything around it, (Schaufeli \& Bakker, 2003).

\section{Factors of Employee Engagement}

Psychological meaningfulness involves a sense of return on investment of oneself in a role of a performance (Kahn, 1992). According to Kahn $(1990,1992)$, the psychological significance can be achieved by the characteristics of the task such as challenging work, variation, allowing the use of different skills, personal wisdom, and the opportunity to make an important contribution.

Kahn (1990) reports that people vary in their engagement as a function of their perception about benefits they receive from the role. Maslach et al. (2001) also suggests that the lack of appreciation and recognition can lead to fatigue. Recognition and appreciation right is important for the engagement. When employees receive appreciation and recognition from their organization, they will feel obliged to respond with a higher level of involvement.

Psychological security involves a sense of capabilty and self-employed without negative consequences (Kahn, 1992). An important aspect of security comes from the amount of care and support provided by their organizations as well as their immediate supervisor. In fact, Kahn (1990) found that supportive interpersonal relationships and trust promoted psychological security. Members of the organization feel secure in a working environment characterized by openness and supportiveness. A supportive environment allows members to experiment and try new things and even fail without fear of consequences (Kahn, 1990). In their empirical test models Kahn, May et al. (2004) also finds that the supervisors' relationship has positive relationship to psychological safety.

Security dimension is identified by Kahn (1990) as involving social situations that are predictable and consistent. Rhoades et al, 2001). A research of organizational justice found that perceptions of fairness are related to organizational outcomes such as job satisfaction, organizational commitment, organizational citizenship behavior, withdrawal, and performance (Colquitt et al., 2001). However, previous studies have not examined the relationship between perceptions of fairness and employee involvement. Influence perceptions of fairness on various outcomes may be partly due to the involvement of employees. In other words, when employees have a high perception of fairness in their organizations, they are more likely to feel obliged to also be fair in how they perform their role by giving more of themselves through a greater degree of involvement. On the other hand, a low perception of fairness is likely to cause employees to withdraw and disengage from their job role. Justice and fairness are also some of the working conditions in Maslach et al. (2001) model of engagement. The lack of justice can worsen fatigue and while a positive perception of fairness can improve engagement (Maslach et al., 2001).

\section{The Consequences of Employee Engagement}

The driving force behind the popularity of employee engagement is that it has positive consequences for the organization. As indicated earlier, there is a general belief that there is a 
correlation between employee engagement and business results (Harter et al., 2002). However, engagement is to build individual-level and if it causes business results, it must first influence the outcome of an individual level. In line with this, there is a reason to expect the employee engagement related to individual attitudes, intentions, and behavior. Although it is not, Kahn (1990) or May et al. (2004) includes the results in their studies, Kahn (1992) suggests that engagement leads to both individual outcomes (i.e. the quality of people's work and their own experience to do the job), and the level of the organization results (i.e., growth and productivity of the organization). Additionally, Maslach et al. (2001) Model treat engagement as a mediating variable for the relationship between working conditions and work a variety of results like fatigue, and it should be linked to outcomes such as increased withdrawals, lower performance, job satisfaction, and commitment (Maslach et al., 2001).

There are a number of reasons to expect the results the engagement and work results. As a starter, the experience of involvement has been described as satisfactory, positive work experiences and state of mind (Schaufeli and Bakker, 2004; Sonnentag, 2003) and it has been found to be associated with good health and positive work influence (Sonnentag, 2003).

\section{Organizational Justice}

Distributive justice is related to personal gain from the allocation of resources within an organization. During the period between the 1950s and 1970s, most studies on organizational justice had focused on the distributive justice, which is based on the theory of social exchange (Colquitt et al., 2005). According to Homans (1958), people develop normative expectations for future exchanges. Individuals involved in the exchange relationship with other people are sensitive to the possibility that one party might be getting more than the other.

Colquitt et al., (2005) states that procedural justice come from the legal dispute (Thibaut \& Walker, 1975). Basic assumption underlying this theory is that individuals are not only influenced by the results they receive, but also by the naturalness of the process used to plan and execute the decision. They suggest six procedural rules that must be observed in the context of allocation. The procedure should: a) follow consistent procedures (consistency), b) be without any self-interest (bias suppression), c) be based on accurate information (accuracy), d) give an opportunity to improve decision (correct ability), e) take into consideration the interests of all represented parties (representation), and f) follow moral and ethical standards (ethicality) .While equity theory is mainly related to private interests that focus on responses to the perceived injustice of the allocation of resources and results in organizations (Greenberg, 1991), the main interest of procedural fairness lies in the rules and procedures that dominate the allocation of external interest results. In this phase, procedural fairness can be called social justice; different from distributive justicewhich can be called private equity. Lind and Tyler (1988) argue that the more one considers the process is fair, the more tolerant the people about the consequences of the process, although the results are considered to be detrimental to them.

\section{Trust to Leaders}

Rousseau et al. (1998) defines trust as "a psychological state comprising the intention to accept vulnerability based on positive expectations of the intentions or behavior of others" (p. 395). As shown in this definition, a willingness to be vulnerable is seen as a core component in defining trust. In addition, risk taking has been discussed as a core introduction or the result of the trust (Mayer et al, 1995 ;. McAllister, 1995; Rousseau et al, 1998). Although trust is often interchanged with the cooperation, trust is distinguished from similar concepts, such as cooperation and confidence, that those concepts do not put others at risk (Mayer et al., 1995). The third necessary condition of trust is interdependence, where the interests of one party 
cannot be achieved without dependence on others. Although both the risks and interdependencies required for the trust arise, the nature of risk and trust to interdependence change increases (Rousseau et al., 1998). The degree of interdependence actually determines the level of trust.

\section{Consequences of Trust}

As the benefits of trust, a number of studies have suggested that companies with a relationship of trust between top management and employees are considered to have an advantage over companies without such relationships (Bromily \& Cummings, 1992; Hosmer, 1995). Nonaka and Takeuchi (1994) argue that trust is the basis for organizational learning through the sharing of knowledge between people. As a consequence of mutual trust, both sharing knowledge and creating knowledge across the facilitated boundaries (Nonaka, 1991). However, trusting the core people sometimes creates organizational crisis. Some people take advantage of the trust of top management to sell the core knowledge to other companies. As Webb (1996) shows that some of them have transformed into a corporate spies, although risktaking behavior is necessary for the organization. As a consequence of trust to an organization or top management, the desired employee attitudes, such as job satisfaction, organizational citizenship behavior, and organizational commitment, has been reported increase significantly, while the employee negative attitude, such as the desire to move, defensive behavior, and monitoring behavior, has been reported to decrease (Aryee et al, 2002 ; Costa, 2003; Deluga, 1994; Dirks \& Ferrin, 2002; Hopkins \& Weathington, 2006; Konovsky \& Pugh, 1994).

Trust to the top management is closely related to employee perceptions of procedural fairness. Korsgaard et al. (2002) finds that managerial trustworthy behavior is significantly correlated with organizational citizenship behavior through moderation role of justice in HR policies. Spreitzer and Mishra (1999) states that the performance of the organization increasingly relies on employee involvement of lower echelons in the decision-making process because they can make better decisions than their superiors with regard to how their work should be done. According to their findings, the trust of supervisors causes delegation of tasks, which will lead to increased organizational performance.

There are several dimensions that can be used to measure trust. Robbins (2002) dimensions of the trust consist of:
1) Integrity
2) Competence
3) Consistency
4) Loyalty
5) The disclosure

Mayer in Burke et al. (2007) suggested that the dimensions of trust are:
1) Capability
2) Kindnss
3) Integrity

Misra in Nyhan (2000) states that the trust has the dimensions:

1) Competent

2) Open

3) Care

4) Reliable 


\section{Employee Satisfaction}

The job satisfaction construct is generally defined as a positive emotional state that reflects the affective response to the employment situation (Locke, 1976). The focus is on task-oriented and short-term in nature (Mowday, Porter, \& Steers, 1982). Some common perspectives which describe job satisfaction with all these approaches having been examined show some degree of supporting evidence. However, there is no concurrent testing of these competing models in the path of comprehensive models.

Two important outcomes of job satisfaction will be explored - absenteeism and turnover. Job satisfaction has been widely examined as a predictor of absenteeism in the literature, including clear models (Brooke \& Price, 1989). The meta-analysis concludes that the relationship is negative and relatively weak (Hackett and Guion, 1985; Farrell \& Stamm, 1988). However, Scott and Taylor (1985) meta-analysis find a strong negative relationship between overall job satisfaction and the frequency of being absent. Other testing result is the turnover. Job satisfaction has been studied as an antecedent for separation in some early big turnover models (Price \& Mueller, 1981; Bluedorn, 1982). The results of empirical tests have shown modest negative relationship between job satisfaction and turnover (Price, 1977; Mobley, Griffeth, Hand, \& Meglino, 1979). Job satisfaction has also been found to have a significant correlation with turnover (Cotton \& Tuttle, 1986).

\section{PREVIOUS RESEARCHES}

Studies on the development of employee engagement have been conducted, but have not found an integrated research between the trust to the leaders, organizational justice and job satisfaction and employee engagement. The importance of employee engagement to obtain positive results for the organization and employees support by Saks (2006), Gill (2012), and Lockwood (2007). Kuang and Dung (2015) found that ethical leadership and organizational justice significantly affect employee engagement. It also found that organizational justice positively affect trust to the leader. Kristanto (2013) found that organizational justice significantly affects employee job satisfaction, in line with the research conducted by Aslam et al. (2010), Akbolat et al. (2015), Amalia (2012), Iqbal (2013), Sareshkeh et al.(2012) and Suhartini and Hakim (2010). Alfifah (2013), and Saputra (2013) found that trust to the leader significantly and positively affects employee job satisfaction. Previous researchers found that job satisfaction significantly have positive effect on employee engagement, as stated by Abraham (2012) and Aabdeen et al. (2016). Organizational justice and trust to the leader have positive relationship with employee engagement stated by Khan and Mubashar (2016) and He et al. (2014).

\section{Framework and Research Hypotheses}

Based on the study of theories of human resource management, leadership, organizational culture and engagement as well as earlier researches then it is prepared the conceptual framework of this research as in Figure 1. Figure 1 illustrates that thare are four variables of the study, namely: organizational justice (X1), trust to the leaders (X2), job satisfaction (Y1), and employee engagement (Y2). The fourth variable is a construct that cannot be measured directly, but is measured using indicators, as illustrated in Figure 1. 


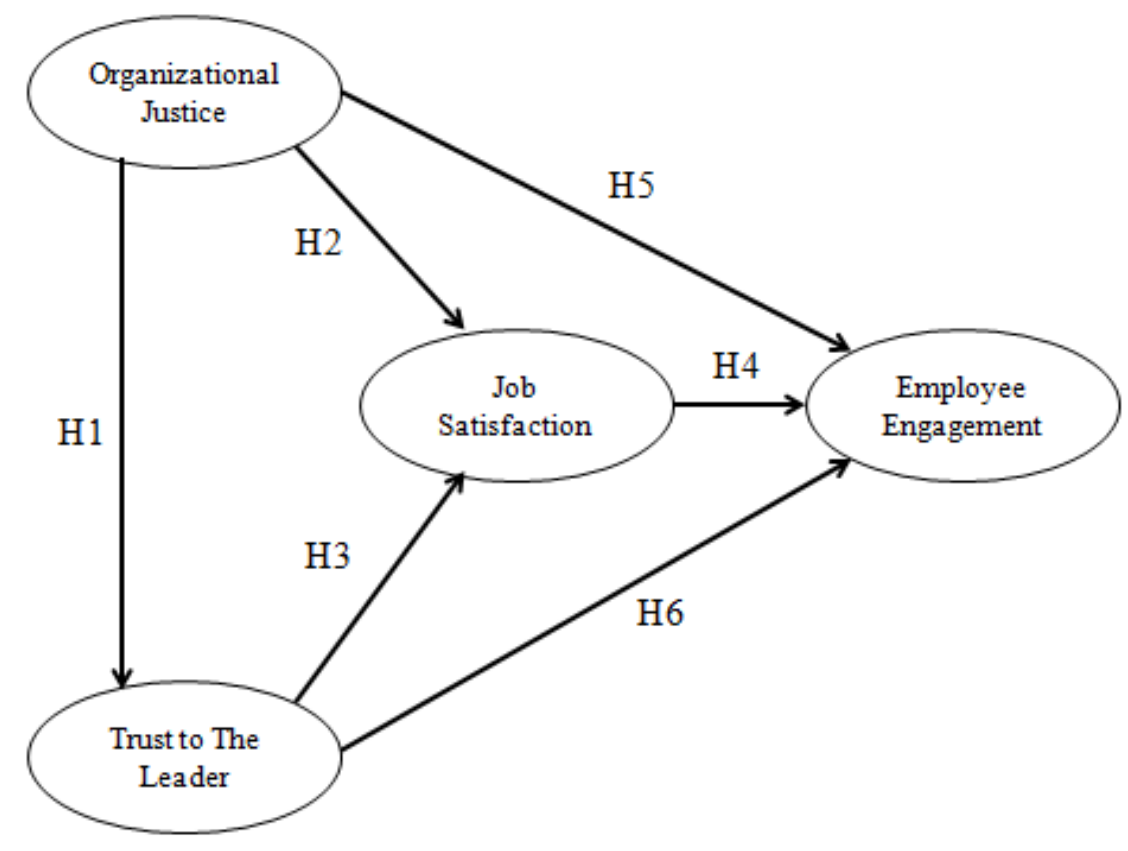

Figure 1. Conceptual Framework

Based on this conceptual framework, the research hypotheses are as follows:

H1: Organizational Justice has a significant effect on trust to the leaders.

H2: Organizational Justice has a significant effect on job satisfaction.

H3: Trust to the leaders has a significant effect on job satisfaction.

H4: Job satisfaction significantly influences employee engagement.

H5: Organizational Justice has significant effect on employee engagement.

H6: The trust to the leaders has a significant effect on employee engagement.

\section{RESEARCH METHODS}

\section{Research Design, Population and Research Samples}

This research is an explanatory research as it aims to explain the influence of variables through hypothesis testing. It is related to human behavior, an explanatory research on the perception of respondents (explanatory perceptional research). The study population is employees of companies from Jabodetabek region that study at Magister Program of Mercu Buana University Jakarta. The samples are taken randomly, as many as 150 employees.

\section{Operational Definition of Research Variables}

Primary data were collected by questionnaire. The questionnaires were distributed directly to the respondents by enumerator who explained how to fill out the questionnaire. By using this technique, it is expected to reduce the differences in interpretation between respondents and the researcher.

Variables of organizational justice (X1); the justice perceived by respondents about the various exchanges that occur in organizations where they work. Likert scale is used to measure (a score of 1 to 5) the dimensions of organizational justice namely: 1) distributive justice (X1.1), 2) procedural justice (X1.2), and 3) interactional justice (X1.3).

Variable trust to the leaders (X2); is defined as a psychological state of a person to accept based on positive expectations of the intentions or behavior of others. This variable is measured by the trust of subordinates or respondents' perception to the leaders with Likert scale (a score 
of 1 to 5 ) on the dimensions of trust to the leaders, namely: 1) Ethical (X2.1), 2) Ability (X2.2), and 3) realiabilty $(\mathrm{X} 2.3)$.

Job satisfaction variable (Y1) is a positive emotional state that reflects the affective response to the employment situation (Locke, 1976). Job satisfaction variables are measured with Likert scale based on the perceptions of employees (a score of 1 to 5) on the dimensions of job satisfaction which consists of: 1) Satisfaction with the work itself (Y1.1), 2) Satisfaction with the supervisor (Y1.2) , 3) Satisfaction of compensation (Y1.3), 4) Satisfaction with work colleagues (Y1.4), and 5) Satisfaction of the employment conditions (Y1.5)

Variable employee engagement (Y2), the employees' perceptions of commitment, pride and willingness to work hard at work at the company where he works. This variable is measured by using a Likert scale (points 1 to 5) using a three dimensional Schaufeli et al. (2009): 1) Vigor (Y21), 2) Dedication (Y22), and 3) Absorption (Y23).

\section{DATA ANALYSIS}

Data were processed by using structural equation (SEM) by using the program package AMOS (Analysis of Moment Structure) version 7. SEM testing can do testing together on: 1) the structural model of the relationship between independent constructs and dependent construct, and 2) relationship relating to the measurement model, which can be seen from the loading value of the indicator and construct (latent variables).With such testing, measurement error becomes an integral part of the model, so that factor analysis could be done jointly by hypothesis testing.

Goodness-of-Fit creteria measure the suitability of observation or actual input (covariance or correlation matrix) with the predictions of the model proposed (proposed model). There are three types of measures Goodness-of-Fit that are used in this research. This testings were conducted to determine whether a variable can be used to confirm that these variables together with other variables can describe a latent variable. The criteria used to assess are the value of loading factor and regression weight.

Statistical test is done by testing whether the regression coefficients equals to zero. The testing is carried out by using t-test. The level of significance of the relationship between variables is done by looking at the value of P (level of significance) and CR relationship between variables respectively. The significance can be seen from the value of the critical ratio or CR; if CR is greater than or equal to 2.00 then the relationship between variables is significant.

\section{Descriptive statistics}

\section{RESULTS AND DISCUSSION}

Descriptive statistics on respondents' answers about the research variables, together with the average score of variable dimensions is shown in Table 1 . The average score of 3.4258 where justice variable of procedural fairness dimensions has a higher score than the dimensions of distributive justice. 
Table 1. Descriptive Statistics, Loading Factor dan Construct Reliability

\begin{tabular}{|c|c|c|c|c|c|c|}
\hline No. & $\begin{array}{c}\text { Variabel } \\
\text { Dimension }\end{array}$ & Mean & $\begin{array}{c}\text { Loading } \\
\text { Factor }\end{array}$ & Validity & $\begin{array}{c}\text { Construct } \\
\text { Reliability }\end{array}$ & Reliability \\
\hline \multicolumn{2}{|c|}{ Organizational Justice } & 3,4258 & & & & \\
\hline 1. & Distributive Justice & 3,3051 & 0,69596 & Valid & 0,881 & Reliable \\
\hline 2. & Prosedural Justice & 3,5249 & 0,65494 & Valid & & \\
\hline \multicolumn{2}{|c|}{ Trust to the Leader } & 3,3082 & & & & \\
\hline 1. & Ethics & 3,2524 & 0,71272 & Valid & & \\
\hline 2. & Reliability & 3,0304 & 0,72851 & Valid & 0,877 & Reliable \\
\hline 3. & Capability & 3,3669 & 0,62974 & Valid & & \\
\hline \multicolumn{2}{|c|}{ Job Satisfaction } & 3,3082 & & & & \\
\hline 1. & Compensation & 3,1886 & 0,79441 & Valid & & \\
\hline 2. & Job & 3,3687 & 0,84087 & Valid & & \\
\hline 3. & Promotion & 3,2655 & 0,80682 & Valid & 0,993 & Reliable \\
\hline 4. & Supervision & 3,3167 & 0,77616 & Valid & & \\
\hline 5. & Coworker & 3,3162 & 0,81413 & Valid & & \\
\hline 6. & Facility & 3,3941 & 0,81702 & Valid & & \\
\hline \multicolumn{2}{|c|}{ Engagement } & 3,4027 & & & & \\
\hline 1. & Vigor & 3,5186 & 0,60849 & Valid & & \\
\hline 2. & Dedication & 3,4595 & 0,66940 & Valid & 0,811 & Reliable \\
\hline 3. & Absorbtion & 3,2293 & 0,68026 & Valid & & \\
\hline
\end{tabular}

Source : Research Data Processed (2016)

Trust variable in the leaders has an average score of 3.3082 where the capability dimension has the highest score compared to the ethical dimension and the reliability dimension. It means taht the respondents have the perception that their superiors have the capacity to execute their tasks. Job satisfaction variable has an average score of 3.3082, where the dimension of satisfaction with the facilities has the highest score, while satisfaction with salary has the lowest score. Engagement variable has an average score of 3.4027 where the vigor dimension has the highest score, while absorption dimension has the lowest score.

\section{Confirmatory Factor Analysis}

The results of significance analysises of confirmatory factor, as presented in Table 1 show that these indicators significantly explain the variables measured. Those are presented in Table 2 . loading factor value of each indicator against the variables measured. 
The validity and reliability testing of the research instrument was done by using criteria loading factor and construct reliability as presented in Table 1 . The criteria used to evaluate the validity of research instrument are the loading factor of 0.6 (Gozali, 2007). Based on these loading factor criteria, instrument used to measure the research variables are all valid because it has a loading factor greater than 0.6.

Reliability was tested with criteria of reliability construct greater than or equal to 0.70 (Ferdinant, 2006), and the results are presented in Table 4.2. The construct reliability value of the four variables is greater than 0.70 , so it can be concluded that the measurement of research variables is reliable, so that the overall measurement of the variables is reliable, making it feasible to do further analyses.

\section{Assumptions and Fit Model}

\section{a. Normality}

The testing of normality assumption was carried out with the skewness and kurtosis, which consists of normality test univariate and normality test multivariate. The test results indicate that there is greater value than two for capability dimension from the variable of trust to the leaders. But considering only one dimension that does not meet the standard, it is still used in the model analysis. Normality test using Mahalanobis was also carried out, in which test results indicate that as many as 10 respondents have Mahalanobis index of less than 0.2 indicating not meet the assumptions of normality or outlier occurs. However, since the amount is less than 10 percent of the data, so it can still be used in the data analysis.

\section{b. Test of Fit Mode}

The fit model in this study was measured with the criteria of significant probability, ChiSquare, RMSEA, GFI, TLI, CFI, AGFI and CMIN/DF. The results of the test indicate that the model is good, since six of the eight criteria are good and the others are moderate.

\section{Results of Hypothesis Test}

The hypothesis tests is presented in Table 2, which tests the hypotheses of research using $\mathrm{P}$ value criteria. If the $P$ value less than 0.05 then the hypothesis is accepted and when greater than 0.05 , then the hypothesis is rejected. There are six research hypotheses, and the 4 hypotheses were accepted; the hypothesis of the influence of organizational justice and trust to the leaders towards the employee engagement through an intervening variable job satisfaction. Hypotheses regarding the effect of organizational justice andtrust to the leaders towards the employee engagement were rejected. The discussion of the results of the testing of hypotheses is presented below. 
Tabel 2. Result of Hypothesis Test

\begin{tabular}{|c|c|c|c|c|c|c|c|}
\hline & & & $\begin{array}{c}\text { Estimat } \\
\text { e }\end{array}$ & S.E. & C.R. & $\mathbf{P}$ & Result \\
\hline Trust & $<---$ & Justice & 0,858 & $\begin{array}{c}0,08 \\
5\end{array}$ & $\begin{array}{c}10,06 \\
8\end{array}$ & $* * *$ & $\begin{array}{l}\text { Hypothesis } \\
\text { accepted }\end{array}$ \\
\hline $\begin{array}{l}\text { Satisfaction } \\
n\end{array}$ & $<---$ & Justice & 0,328 & $\begin{array}{c}0,15 \\
4\end{array}$ & 2,128 & 0,033 & $\begin{array}{l}\text { Hypothesis } \\
\text { accepted }\end{array}$ \\
\hline $\begin{array}{l}\text { Satisfaction } \\
\mathrm{n}\end{array}$ & $<---$ & Trust & 0,576 & $\begin{array}{c}0,16 \\
3\end{array}$ & 3,539 & $* * *$ & $\begin{array}{l}\text { Hypothesis } \\
\text { accepted }\end{array}$ \\
\hline $\begin{array}{l}\text { Engagemen } \\
t\end{array}$ & $<---$ & $\begin{array}{l}\text { Satisfactio } \\
\text { nn }\end{array}$ & 1,137 & $\begin{array}{c}0,33 \\
1\end{array}$ & 3,433 & $* * *$ & $\begin{array}{l}\text { Hypothesis } \\
\text { accepted }\end{array}$ \\
\hline $\begin{array}{l}\text { Engagemen } \\
t\end{array}$ & $<---$ & Justice & $-0,059$ & $\begin{array}{c}0,21 \\
7\end{array}$ & $\begin{array}{c}- \\
0,273\end{array}$ & 0,785 & Hypothesis rejected \\
\hline $\begin{array}{l}\text { Engagemen } \\
\mathrm{t}\end{array}$ & $<---$ & Trust & $-0,507$ & $\begin{array}{c}0,29 \\
5\end{array}$ & $\begin{array}{c}- \\
1,720\end{array}$ & 0,086 & Hypothesis rejected \\
\hline
\end{tabular}

Sources : Research Data Processed (2016)

\section{HYPOTHESIS 1: JUSTICE HAS A SIGNIFICANT EFFECT ON TRUST}

The first hypothesis, that justice has a significant effect on trust to the leaders is accepted, with positive direction. It means that the higher the score organizational justice consisting procedural justice, distributive justice felt by the respondents, the higher the trust to the leaders score, which is reflected in the ethical, reliable, and capable dimensions. The results support previous research conducted by Kuang and Dung (2015), which shows that justice affects the employees' trust to the leader.

\section{HYPOTHESIS 2: JUSTICE HAS A SIGNIFICANT EFFECT ON JOB SATISFACTION}

The hypothesis that justice has a significant effect on trust to leaders is accepted, with a positive direction. It means that the higher the score of justice perceived by the respondents, the higher the score trust to leaders, which is reflected in the ethical, reliable, and capable dimensions. The results of this study support the research by Kris (2013) who conducted research at PT. Power Indonesia. Other research results by Aslan et al. (2015) also show that organizational justice, procedural, distributive, and interactional, has positive and significant impact on job satisfaction. Studies evaluating the effect of organizational justice on job satisfaction have been widely conducted and show the results that support one another, such as the research conducted by Suhartini and Hakim (2010), Akbolat et al. (2015), Amalia (2012), Iqbal (2013), as well as Sareshkeh et al. (2012). The results of this research suggest that organizational justice is an important factor in achieving employee satisfaction.

\section{HYPOTHESIS 3: THE TRUST TO THE LEADERS INFLUENCES SIGNIFICANTLY ON EMPLOYEE SATISFACTION}

The hypothesis that justice has a significant effect on trust to the leaders is accepted, with a positive direction. It means that the higher the score of justice perceived by the respondents, the higher the score of trust to the leaders, which is reflected in the ethical, reliable, and 
capable dimensions. As stated by Robbins (2010) that trust is the foundation of leadership. Based on trust, the employees will have the spirit in achieving the organizational performance. The results of this study also support the results of previous studies conducted by Alfiah for example (2013) which states that trust to leaders has positive and significant impact on job satisfaction, and mediates the effect of the conflict on job satisfaction. This research also supports research conductedby Saputra (2013) which states trust to leaders has a direct positive and significant influence on employee satisfaction.

\section{HYPOTHESIS 4: EMPLOYEE SATISFACTION INFLUENCES SIGNIFICANTLY ON EMPLOYEE ENGAGEMENT}

The hypothesis that justice has a significant effect on trust to the leaders is accepted, with apositive direction. It means that the higher the score of justice perceived by the respondents, the higher the score of trust to the leaders, which is reflected in the ethical, reliable, and capable dimensions. The relationship between job satisfaction and employee engagement has been discovered by some researchers, but in this case there are two groups. The first group states that job satisfaction is a result of the employee engagement, among others by Lee (2012), while the second group states that job satisfaction is a factor that encourages employee engagement, as Robinson et al. (2004: 23), and research by Abraham (2012).

\section{HYPOTHESIS 5: JUSTICE HAS A SIGNIFICANT EFFECT ON ENGAGEMENT}

The hypothesis that justice significantly influences employee engagement is not accepted, then justice has no significant effect indicated by the $\mathrm{P}$ value smaller than $\mathrm{P}$ value table and the significance level is greater than 0.05 . The results of this study do not support previous research by Alfiah (2013) and Saputra (2013), which both say that justice influences employee engagement. These results indicate that the effect of justice on employee engagement is indirect, through variable job satisfaction. It means that justice will make employees satisfied and satisfied employees will have higher engagement.

\section{HYPOTHESIS 6: THE TRUST TO THE LEADERS INFLUENCES ENGAGEMENT}

The hypothesis that justice significantly influences employee engagement is not accepted. It means that the trust to the leaders does not influence significantly the employee engagement. This is indicated by the value $\mathrm{P}$ value less than $\mathrm{P}$ value table and the significance level is greater than 0.05 . The results of this study do not correspond with the results of the previous studies such as MacLeod and Clarke (2009) and Menguc et al, (2012) which state that the trust of employees to their leaders determines the level of their engagement. The leaders should be the people who are trusted by their men because the trust to the immediate supervisors should be the factor that most influences the attitudes and behavior of employees. The effect of trust to the leaders affects directly the employee engagement through intervening variables job satisfaction, so trust your leaders will increase customer satisfaction, and satisfied employees will have high engagement.

\section{CONCLUSIONS AND RECOMMENDATIONS CONCLUSION}

1. Organizational justice influences significantly employees' trust to their immediate superiors.

2. Organizational justice influences significantly on employee job satisfaction.

3. Trust to the leaders has a significant effect on employee job satisfaction.

4. Employee satisfaction influences significantly the employee engagement.

5. Organizational justice has no significant effect on employee engagement.

6. The belief in the leadership had no effect on employee engagement. 
7. Based on the conclusion number 6 above, justice and trust to the learders has a positive and significant impact on employee engagement, but through job satisfaction as a mediating variable.

\section{Suggestion}

The research suggests that organizational justice and trust to the leaders should always be maintained so that the morale and the positive outcomes of the organization can be achieved.

\section{References}

Abraham, Susan. 2012. Development of Employee Engagement Programme on the basis of Employee Satisfaction. Journal of Economic Development, Management, IT, Finance and M arketing, Vol.4, No.1, pp: 27-37.

Akbolat, Mahmud, Oguz Isik, Ali Yilmaz, Nesrin Akca, 2015. The Effect of Organizational Justice Perception on Job Satisfaction of Health Employees. International Journal of Recent Advances in Organizational Behaviour and Decision Sciences (IJRAOB) An Online International Research Journal (ISSN: 2311-3197) 2015 Vol: 1 Issue 2.

Alfiah, Jenefi. 2013. Pengaruh Konflik terhadap Kepuasan Kerja melalui Kepercayaan . Jurnal Ilmu Manajemen, Vol. 1, No.1, pp: 197-208.

Amalia, Rizki. 2012. Analisis Pengaruh Peranan Persepsi Keadilan terhadap Komitmen Afektif dan Kepuasan Kerja di antara Karyawan non Keluarga. Skripsi Universitas Indonesia, Depok.

Aslam, Rabia, Sadaf Shumaila, Shama Sadaqat, Hira Bilal, Mehwish Intizar.2015. Organizational Justice as A Predictor of Job Satisfaction. Proceedings of 2nd International Conference on Business Management (ISBN: 978969-9368-06-6).

Bagyo, Yupono. 2013. Engagement as a Variable to Improve the Relationship between Leadership, Organizational Culture on the Performance of Employees. IOSR Journal of Business and Management (IOSR-JBM), Vol.14, No.4.

Burke, C. Shawn, Dana E Sims, Elizabeth H. Lazzara, Eduardo Salas. 2007. Trust in Leadership : A multilevel review and integration. The Leadership Quarterly, 18: 606-632.

Elfindri, Fitri Rasmita, Revita Bertha Engel, Jemmy Rumengan, Muhammad Basri Wello, Poltak Tobing, Fitri Yanti, Elfa Eriyani,H. Rowayati Zein, Ristapawa Indra.2010. Soft Skills: untuk Pendidik. Praninta Offset, Baduose Media.

Gill, Preetinder Singh. 2012. An Investigation of Employee Engagement and Business Outcomes at an Engineering Services Firm. Dissertation Submitted to the College of Technology Eastern Michigan University.

He, Hongwei, Weichun Zhu, and Xiaoming Zheng. 2014. Procedural Justice and Employee Engagement: Roles of Organizational Identification and Moral Identity Centrality. Journal of Business Ethics, Vol.122, pp:681-695.

Iqbal, Kamran. 2013 Determinants of Organizational Justice and its impact on Job Satisfaction. A Pakistan Base Survey. International Review of Management and Business Research Vol. 2 Issue.1,pp:48-56.

Kahn, W.A. (1990) 'Psychological conditions of personal engagement and disengagement at work', Academy of Management Journal, 33, 692-724.

Khan, Seemal Mazhar and Tahira Mubashar, 2016. Percieved Organizational Justice, Trust and Employee Engagement in Bank Managers. International Journal of Psychological and Behavioral Sciences Vol.3, No.1, pp:421429.

Kilic, Taskin, Sedat Bostan, and Witold Grabowski. 2015. A New Approach to The Organizational Justice Concept : The Collective Level of Justice Perception. International Journal of Health Science, Vol3, No,1, pp:157-175.

Kristanto, Sentot.2013. Pengaruh Keadilan Organisasional terhadap Kepuasan Kerja dan Dampaknya terhadap Komitmen dan Intensi Keluar di PT Indonesa Power UBP Bali .Tesis Program Magister Universitas Udayana.

Kuang, Mai Ngoc and Do Thi Thuy Dung, 2015. The Effect of Ethical Leadership and Organizational Justice on Employee Engagement - The Mediating Role of Employee Trust. International Journal of Trade, Economics and Finance, Vol.6, No.4, pp:235-240.

Lockwood, Nancy R (2007), Leveraging Employee Engagement for Competitive Advantage: HR's Strategic Role. $H R$ Magazine, Mar 2007, Vol. 52 Issue 3, Special section p1-11,11p. 
Medlin, Bobby dan Ken Green, Jr. 2008. The Relationship Among Goal Setting, Optimism, and Engagement: The Impact on Employee Performance. Proceedings of the Academy of Organizational Culture, Communications and Conflict, Vol.13, No.1, pp 51-57.

Rizwan, Muhammad, Zain Ul Aabdeen, Mula Nazar Khan, Moazzam Rehman, and Hafiz Gohar Mehmoof Khan,. 2016. Impact of Performance Appraissal Justice on Employee Engagement on Industrial Sector. Imperial Journal of Interdisciplinary Research, Vol.2, No,5. Pp :1563-1569.

Robertson, Ivan T., Alex Jansen Birch, dan Cary L. Cooper. Job and work attitudes, engagement and employee performance. Leadership \& Organization Development Journal, Vol. 33, No. 3.

Sareshkeh, Sivash Khodaparast, Fatemeh Ghorbanalizadeh Ghaziani2, Seyed Morteza Tayebi. 2012. Impact of Organizational Justice Perceptions on Job Satisfaction and Organizational Commitment: The Iranian Sport Federations Perspective. Annals of Biological Research, Vol. 3, No.8), pp: 4229-4238.

Saputra. Beny Mahyudi. 2013. Pengaruh Gaya Kepemimpinan Transformasional terhadap Kepuasan Kerja melalui Kepercayaan Karyawan pada Atasan (Studi pada STT, STMIK, STBA dan Politeknik Cahaya Surya).Jurnal Otonomi. , Vol. 13, No.1, Pp: 117-126.

Suhartini \& Maulana Ikwanul Hakim. 2010. Pengaruh Keadilan Organisasional terhadap Kepuasan Kerja Karyawan Fakultas Ekonomi Universitas Islam Indonesia. Jurnal Solusi, Volume 5, Nomor 2, Pp:75-91.

Warongan, Jonathan B., Greis M. Sendow dan Imelda W. Ogi. 2014. Pengaruh Kompetensi, Komitmen Organisasi dan Keterlibatan Kerja terhadap Kinerja Karyawan pada PT. PLN (Persero) wilayah Suluttenggo. Jurnal EMBA. Vol.2, No.4, pp 331-342. 